\title{
ANGST OVER UNIVERSITY RANKINGS
}

\section{Aw TC, Sharif A}

Department of Community Medicine, Faculty of Medicine \& Health Sciences, UAE University, Al-Ain, United Arab Emirates

\section{Correspondence:}

Aw Tar Ching

Chair, Department of Community Medicine

Faculty of Medicine \& Health Sciences

United Arab Emirates University

PO Box 17666

Al-Ain, United Arab Emirates

Email: tcaw@uaeu.ac.ae

Universities wait with trepidation each year when university rankings are published. These rankings are often viewed as indicating 'excellence', providing prestige as well as attracting potential students and possible research or other funding. Several organizations produce composite indices which are used to rank universities worldwide. Two of the best known indices are the Times Higher Education (THE) and the Quacquarelli Symonds (QS) world university rankings $[1,2]$. They were originally part of one ranking system, but separated in 2010 with each producing its lists based on their own criteria, resulting in different universities taking the top spots.

The University of Cambridge must have been delighted to be ranked first when the QS list appeared in the middle of 2010. They beat Harvard University who had otherwise been top of the list every year since 2004. Yale was placed third and University College London fourth. Their delight might have been short-lived as the THE list ranked them joint $6^{\text {th }}$ (with University of Oxford) when this list appeared only a few weeks later, and Harvard reclaimed its top position in the THE rankings.

It is competitive at the top, and I wondered how my alma mater - The University of Malaya (UM), fared. The 2010 QS rankings have separate lists for world universities, regional and in-country universities [2]. In the most recent listings, while UM did not make the top 200 in the world, it ranked highest amongst universities in Malaysia. Universiti Kebangsaan Malaysia (UKM) was second placed and third Universiti Sains Malaysia (USM). How did UM compare with other universities in Asia? 2010 QS rankings had the University of Hong Kong at number one (ranked $21^{\text {st }}$ worldwide); the Hong Kong University of Science and Technology $2^{\text {nd }}$, and the National University of Singapore third. UM was $42^{\text {nd }}$ on the list.

Are universities doing better over time, or are their rankings declining against the competition? The THE-QS data for years 2004 to 2009 (all the years when THE and QS both shared the same system) showed some interesting trends. Figure 1. indicates the change in worldwide rank for the current top three Asian universities.

In 2010, both the THE list and the now separate QS list had The University of Hong Kong as the top Asian University. But unlike the QS rankings, the THE list had the National University of Singapore ranked higher than the Hong Kong University of Science and Technology (HKUST). THE ranked NUS $4^{\text {th }}$ and HKUST $6^{\text {th }}$. On the basis of these lists, the University of Hong Kong could claim justifiably to be the leader of the pack. Depending on the yardstick chosen, the other selected Asian universities could also find reasons to be contented. 


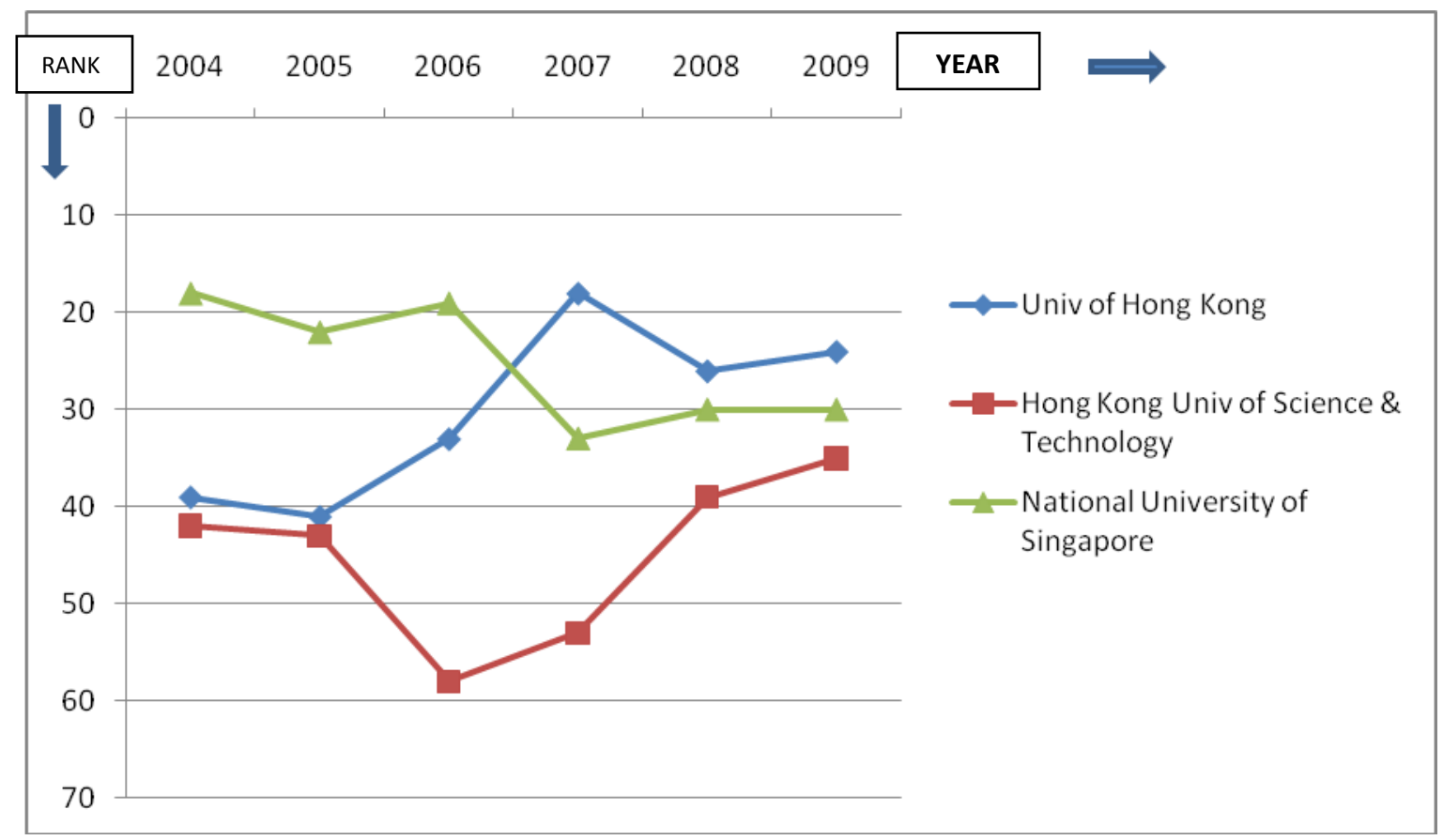

Figure 1. THE-QS University rankings for three Asian universities over time. Note that the previously combined THE-QS rankings in 2010 was split into two separate independent lists, and therefore the 2010 ranks are not shown in the figure

What about universities in the Middle East? Institutions in Saudi Arabia seem to do well in the QS rankings e.g. King Saud University and King Fahd University of Petroleum and Minerals. Over the past few years the United Arab Emirates University (UAEU), like many other institutions for higher learning, has also been making efforts to improve its ranking. UAEU was not listed in 2007; it entered the top 500 list in 2008; and improved to position 374 in 2009 and to 372 in 2010 . This is comparable to the progress made by e.g. University Teknologi Malaysia (UTM), Heriot-Watt University, UK and the American University of Beirut (AUB). However, there is still a long way to go yet before these universities enter the top 200. And even when a university is in the top 200 , there is anxiety when it drops a position or two e.g. when the University of Malaya moved from position180 to 207. Newspaper headline phrases such as "plummeted in position" and "dropping out of the top 200" merely served to raise heckles.

There are also regional ranking systems. SESRIC (Statistical, economic and social research and training centre for Islamic countries) on behalf of the Organisation of the Islamic Conference (OIC) used a composite index to rank over 300 universities from 49 Islamic countries [3]. The index was based on a weighting system for 4 research domains - research quality $(35 \%)$, research performance $(35 \%)$, research volume $(18 \%)$, and rate of growth for research quality (12\%). In their 2007 analysis, the UAE University was ranked $9^{\text {th }}$, UKM $12^{\text {th }}$ and UM $14^{\text {th }}$. SESRIC does not appear to have published a further ranking exercise since then.

The Shanghai ranking or Academic ranking of world universities (ARWU), compiled by the Shanghai Jiao Tong University is another well-established ranking system [4]. It allocates a score for 4 different main categories: Quality of education (10\%); Quality of faculty (40\%); Research output (40\%); and Per capita academic performance $(10 \%)$. They take into account Nobel prizes won by staff and alumni; the number of highly cited researchers; and papers published in Nature and Science. As these two journals may not be the preferred avenue for papers published by social scientists, allow- 
ance is made for other journals to be considered for humanities and social science institutions. Academic staff with Nobel prizes can be expensive to attract or retain, and this is a disadvantage for universities in developing countries if they are trying to improve their rank according to the Shanghai index.

The basis for ranking determines how well or how badly a university performs. The main focus is often on the position in the league tables, with less attention on the criteria used. The range of criteria includes faculty/student ratio, class size, faculty salaries, and proportion of professors with relevant higher degrees. Some systems put a weighting on the proportion of international students and staff. Universities that restrict their student intake to only their own nationals will lose on the international students score. Salary levels may also determine the proportion of international faculty members, and universities in low GDP (Gross Domestic Product) countries will have a disadvantage in this regard. A limitation of the old THE-QS system was the allocation of a weighting based on the 'subjective results of a reputation survey' [5]. The new THE system has attempted to improve their methodology by increasing the number of performance indicators from six to thirteen (organized into five categories - Research indicators, institutional indicators, international diversity and economic activity/innovation) [5]. The inclusion of more indicators does not necessarily lead to a better index. The inclusion or exclusion of some domains that could be considered relevant or important by others, and the allocation of weights to different categories will remain contentious.

The Spanish-based non-profit 'Webometrics Ranking web of world universities' ranks universities not only using journal-based research publications, but also from search engine findings (e.g. Google Scholar). They also rely on academic information from the universities' web pages, updating their findings twice a year [6]. Their data show a separate list for South East Asian universities, in which the most recent (January 2011) had NUS top of the list, and the Malaysian universities in this order: USM $-10^{\text {th }}$, UTM $12^{\text {th }}$, UKM $13^{\text {th }}$, UPM (Universiti Putra Malaysia) $16^{\text {th }}$, UM $17^{\text {th }}$. Universiti Malaysia Perlis was next at $21^{\text {st }}$.

If a university does not like a particular ranking system, it can refrain from participating, look for a different process, or highlight the deficiencies of the current procedures. There are plenty of choices for systems to rank universities. There all have their limitations and are subject to criticisms $[7,8,9]$. Those who do well will laud the system, and those who do not may criticize it, and/or develop their own rankings. For example, countries from Iran to Pakistan have all developed independently a ranking process for their local universities $[10,11]$. This could well act as a guide for home students when they apply to local universities, although the students (and their parents or whoever funds their higher education) could just as well consider the QS, THE, or other rankings. The availability of ranking systems is considerable, yet new systems continue to be developed. In 2009 the European Commission initiated a project with a budget exceeding a million euros for a new 'multidimensional, independent, transparent, global system' [12]. A report on this project is anticipated in 2011. However, attempts to develop new systems are likely to end up introducing other limitations. It is possible that ranking systems themselves could be the subject of ranking, and that would certainly lead to more controversy and debate.

With so many ranking systems available, it is ultimately a case of "you pays your money, and you takes your choice" (as the popular, but grammatically incorrect saying goes). Universities will need to take heed of their ranks in these lists, as much as the general public or their current and future staff and students. But perhaps there should not be too much over concern regarding rankings. If universities and their staff have tried their level best in regards to research, teaching, service and output from other academic or related activity, then there ought to be some ranking system somewhere that will rank them high. June/July 2011 approaches, and there is likely to be 
sharp intakes of breath while waiting for the appearance of the next round of published rankings, with the usual expected responses from universities, governments, and the public.

\section{Declaration of interests}

Aw Tar Ching is a graduate from the University of Malaya (UM), and is currently a professor at the United Arab Emirates University (UAEU).

\section{Footnote:}

This paper was written and submitted in April 2011. Since then, a more recent QS World University rankings for 2011 was released on $5^{\text {th }}$ September 2011 [13]. Among the universities in Malaysia, the new rankings are likely to have been met with much delight by the University of Malaya. It remained the top-ranked university in the country, and is the only Malaysian university ranked in the top 200 . There might well be disappointment and rationalization in other universities as their rankings declined. The three leading Asian universities shown in Figure 1, retained their relative positions -the University of Hong Kong (ranked 22) remained in top position; the National University of Singapore was next (ranked 28); and the Hong Kong University of Science and Technology dropped to rank 40 (it was overtaken by the Chinese University of Hong Kong at rank 37). The United Arab Emirates University improved its ranking from position 372 in 2010 to 338 in 2011. [2] It could be interesting to see the order of the universities when the Times Higher Education list appears on October 6th. [14]

\section{References}

1. The Times Higher Education World University Rankings. Top 200 world universities. http://www.timeshighereducation.co.uk/world-university-rankings/ Accessed on 8 Feb 2011.
2. QS Top Universities. QS World University Rankings. http://www.topuniversities.com/university-rankings/world-university-rankings/2011 Accessed on 8 Feb 2011.

3. SESRTCIC. Academic ranking of universities in the OIC countries.

http://www.sesric.org/files/article/232.pdf Accessed 8 Feb 2011.

4. Liu NC, Cheng Y. Academic ranking of world universities - Methodologies and problems. Higher education in Europe 2005; 30(2): 1-14.

5. Baty P. THE unveils broad, rigorous new rankings methodology. Times Higher Education (3 June 2010). Available at:

http://www.timeshighereducation.co.uk/story.asp?storycode $=411907$ Accessed 7 Feb 2011.

6. The ranking Web of world universities. http://www.webometrics.info/ Accessed 6 Feb 2011.

7. Butler D. University rankings smarten up. Nature 2010; 464(7285): 16-17.

8. Charon A, Wauters J-P. University rankings: a new tool for the evaluation of higher education in Europe. Nephrol Dial Transplant 2008; 23(1): 62-64.

9. Ghabili K, Shoja MM, Ghabili S. The neglected role of students in international university rankings. Nephrol Dial Transplant 2008; 23(5): 1774-1775.

10. Payvand Iran News. Iran's university rankings published. http://www.payvand.com/news/11/Jan/1095.html Accessed 6 Feb 2011.

11. Higher Education Commission, Pakistan. Ranking of universities.

http://hec.gov.pk/insidehec/divisions/QALI/others/rankingofuniversities-/pages/default.aspx Accessed 6 Feb 2011.

12. European Commission, Education and training. News: Commission launches university ranking project. 
http://ec.europa.eu/education/news/news1103 en.ht

m accessed 8 Feb 2011.

13. The Guardian The top 200 QS World University

Rankings 2011-10-03

http://www.guardian.co.uk/higher-education-

network/2011/sep/05/top-200-world-universities-

rankings-2011 Accessed 29 Sept 2011

14. Times Higher Education (THE). World university rankings launch date revealed.

http://www.timeshighereducation.co.uk/story.asp?sect

ioncode $=26 \&$ storycode $=417345 \& \mathrm{c}=2 \quad$ Accessed 4

Oct 2011 